\title{
Optic disc pit with serous macular detachment in a child
}

\author{
Seröz maküler dekolmanlı optik disk çukurluğu bulunan bir çocuk
}

\author{
Refik Oltulu $^{1}$ İsmail Erşan ${ }^{2}$, Günhal Şatirtav ${ }^{1}$, Mehmet Okka ${ }^{1}$
}

\begin{abstract}
Optic disc pits occur in less than 1 in 10.000. Approximately $50 \%$ of cases of congenital optic disc pits are associated with serous macular detachment. Long-standing serous detachments are usually associated with cystic degeneration of the macula and loss of pigment from the underlying retinal pigment epithelium. Hence, most eyes with serous macular detachment associated with an optic disc pit have a relatively poor visual prognosis. We represent a 9-year-old girl with a right optic disc pit associated with serous retinal detachment of the macula. Our experience underline that clinicians must be vigilant about the assessment of optic disc pit and furthermore in the diagnosis of optic disc pit, careful and close ophthalmologic examination for macular detachment is recommended for early diagnosis.
\end{abstract}

Key words: Coloboma, macular degeneration, optic nerve, retinal detachment

\section{INTRODUCTION}

Optic disc pit (ODP), also known as atypic coloboma is attributed to incomplete closure of the fetal fissure. ODP usually occurs during the first trimester of embryogenesis [1]. It occurs in less than one in 10000 people [2]. An ODP appears as an oval or round, gray, white, or yellowish crater-like depression in the optic disc. ODP is frequently situated in the temporal or infra-temporal region of the optic disc [3]. ODP varies from one-fourth of a disc diameter to one-half or more disc diameter in size and depth, and unilateral in $85-90 \%$ of cases [4]. Visual acuity usually remains unaffected unless the patient develops a serous retinal detachment of the macula. Although ODP is a rare condition of the optic disc, most of the patients with ODP develop serous

\section{ÖZET}

Bu yazıda nadir görülen, seröz maküler dekolmanlı optik disk çukurluğu bulunan çocuk olguyu sunuyoruz. Optik disk çukurları 10000'de 1'den daha az görülür ve olguların \%10-15'inde iki taraflıdır. Doğumsal optik disk çukuru olgularının yaklaşık \%50'si seröz makula dekolmanı ile ilişkilidir. Uzun süre devam eden seröz dekolmanlar genellikle makülanın kistik dejenerasyonu ve alttaki retinal pigment epitelinden pigment kaybı ile ilişkilidir. Bundan dolayı, seröz maküla dekolmanı olan gözlerin çoğunda optik disk çukuru oluşumu ile birlikte göreceli olarak kötü görsel prognoz vardır. Burada seröz dekolmanlı optik disk çukuru olan çocuk olgunun değerlendirilmesinin klinik önemini vurguladık.

Anahtar kelimer: Kolobom, maküla dejenerasyonu, optik sinir, retina dekolmanı

macular detachments [1]. Approximately one-third to two thirds of patients with optic pits develop serous macular detachments. These may occur during childhood or late in life but are most common between the ages of 20 and 40. Although spontaneous reattachment has been reported, most eyes with macular detachment associated with an optic disc pit have a relatively poor visual prognosis [5-7].

In this paper we present a child who ODP with serous macular detachment which is a rare abnormality. The patient's father was informed and then a written informed consent was obtained.

\section{CASE REPORT}

A 9-year-old child presented to us with complaints of blurred vision in right eye started a week ago. On

\footnotetext{
${ }^{1}$ Department of Ophthalmology, Meram School of Medicine, Necmettin Erbakan University, Konya, Turkey

2 Department of Ophthalmology, Ministry of Health, Aksaray State Hospital, Turkey

Yazışma Adresi /Correspondence: Refik Oltulu,

Dept. Ophthalmology, Meram School of Medicine, Necmettin Erbakan University, Konya, Turkey Email: refikoltulu@gmail.com

Geliş Tarihi / Received: 09.04.2013, Kabul Tarihi / Accepted: 30.04.2013

Copyright (C Dicle Tıp Dergisi 2013, Her hakkı saklıdır / All rights reserved
} 
examination, her uncorrected visual acuities were 10/10 left and 4/10 right eye. There was no improvement with correction. Both anterior segments were normal, with normal intraocular pressures. Indirect ophthalmoscopy and slit lamp biomicroscopy showed ODP along with associated serous macular detachment in the right eye (Figure1) and the left fundus was normal. Optic disc pit located temporally and was one-third of the disc diameter.

She underwent optical coherence tomography (OCT) showed subretinal fluid accumulation in the macular area on the right eye (Figure 2). The patient was followed for one month, but we did observe any recovery and the corrected visual acuity was $1 / 10$ on the right eye. The patient's father was informed that the treatment of her right eye and a barrage laser photocoagulation to the peripapillary retina was applied (Figure 3 ). In addition, he was informed that vitreoretinal surgical intervention may be performed if necessary. Two months after the photocoagulation we did not find any improvement; so we planned to perform pars plana vitrectomy (vitreoretinal surgery). However, the patient's father disapproved the recommended treatment and the patient was followed up closely.

\section{DISCUSSION}

Optic disc pit is a rare congenital abnormality of the optic disc, which does not cause patients to complain unless macular involvement occurs. In many cases, optic disc pits are incidentally discovered at routine fundus examination. It has been known that it may develop serous macular detachment, which causes serious vision loss in great amount of optic pits.

Patient age at the onset of the macular detachment associated with optic disc pit is variable, with a mean of 30 years [8]. The serous macular detachments that may affect visual acuity are usually related to pits in the temporal region of the optic disc [9]. The mechanism of production of the subretinal fluid associated with a serous retinal detachment is still unclear. The most popular theory is that fluid from the vitreous leaks through the optic pit and fills the sub-retinal space [10]. Optic disc pit is most commonly unilateral as in this case [3]. However, bilateral cases have been reported [11].
Treatment includes argon laser to the peripapillary region, pneumatic displacement of the submacular fluid, macular buckling surgery, vitrectomy combined with laser and/or gas injection $[9,12]$. Attempts to repair the macular detachment and improve visual acuity should be considered before prolonged detachment results in irreversible degenerative changes [12].

Only a few pediatric cases managed with vitrectomy surgery have been reported in the literature. Snead et al. reported a case of a 9-year-old boy with optic disc pit maculopathy successfully treated with vitrectomy, endolaser, and SF6 tamponade without internal limiting membrane peel [13]. Hirakata et al. treated an 8-year-old girl with vitrectomy and gas, while an unusual posterior hyaloid strand connected with the optic disc pit was removed with forceps [14]. Laser photocoagulation followed by vitrectomy, internal limiting membrane peeling, and gas tamponade was performed with favourable results by Ishikawa et al. in a 7-year-old girl with optic disc pit maculopathy [15]. Ghosh et al. retrospectively reviewed the outcome of vitrectomy, laser photocoagulation, and gas tamponade in 7 patients; among them 2 were children, 7 and 11 years old. In both patients, the macula was flattened postoperatively; however, 1 of them required further surgery [16]. Recently, Georgalas et al. treated a 5-year-old boy with vitrectomy, internal limiting membrane peeling, and air tamponade [17].

We perform the barrage laser photocoagulation to the peripapillary retina at the first step. Two months later we observed that the retinal detachment persisted but the father of the patient refused further treatment. Although congenital ODP with serous macular detachment in a child is a rare clinical condition, ophthalmologists should be aware of the lifetime risk of serous macular detachment in patients with congenital ODP and take into consideration the possibility of central visual acuity loss with this complication. The barrage laser photocoagulation to the peripapillary retina may not be enough for those patients and further surgical treatment may be necessary. It should also be remembered that maculopathy may develop in the eyes at different times. The patients should be informed about the vision loss and followed closely. 


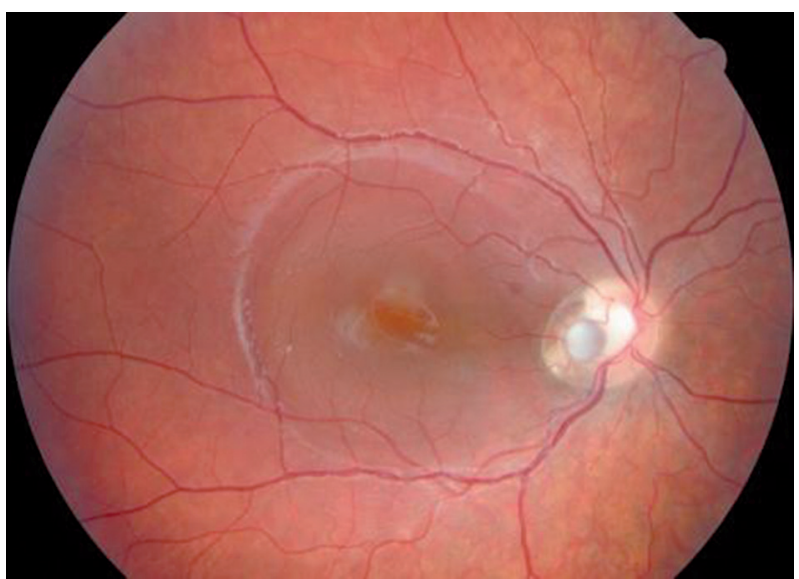

Figure 1. Optic disc pit with serous macular detachment on the right eye

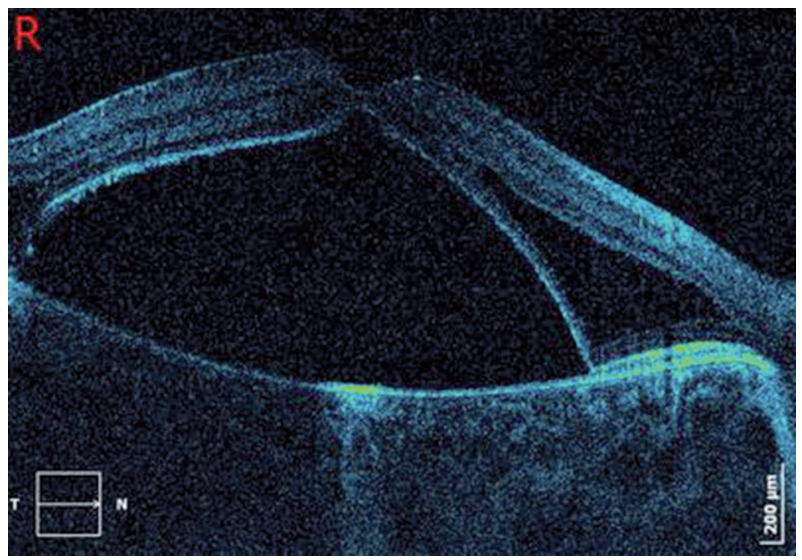

Figure 2. Optical coherence tomography showed subretinal fluid accumulation in the macular area on the right eye

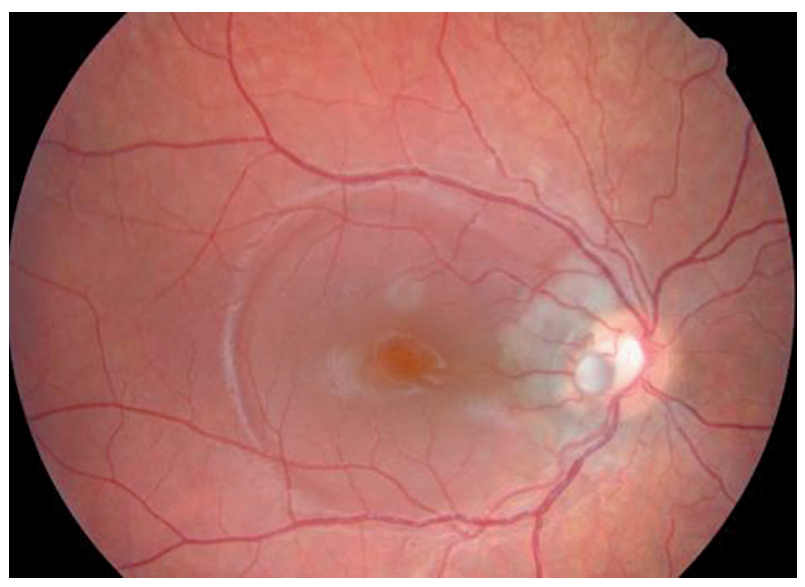

Figure 3. Barrage laser photocoagulation to the peripapillary retina

\section{REFERENCES}

1. Krivoy D, Gentile R, Liebmann JM, et al. Imaging congenital optic disc pits and associated maculopathy using optical coherence tomography. Arch Ophthalmol 1996;114:165-170.

2. Kranenburg EW. Crater-like holes in the optic disk and central serous retinopathy. Arch Ophthalmol 1960; 64:912-924.

3. Brown GC, Shields JA, Goldberg RE. Congenital pits of the optic nerve head: II. Clinical studies in humans. Ophthalmology 1980;87:51-65.

4. Rosenthal G, Bartz-Schmidt KU, Walter P, Heimann K. Autologous platelet treatments for optic disc pit associated with persistent macular detachment. Graefes Arch Clin Exp Ophthalmol 1998; 236:151-153.

5. Theodossiadis G, Panopoulos M, Kollia A, Georgopoulos G. Long-term study of patients with congenital pit of the optic nerve and persistent macular detachment. Acta Ophthalmol 1992;70:495-505.

6. Akiba J, Kakehashi A, Hikichi T, Trempe CL. Vitreous findings in cases of optic nerve pits and serous macular detachment. Am J Ophthalmol 1993;116:38-41.

7. Bonnet M. Serous macular detachment associated with optic nerve pits. Graefes Arch Clin Exp Ophthalmol 1991;229:526-532.

8. Hirakata A, Okada AA, Hida T. Long-term results of vitrectomy without laser treatment for macular detachment associated with an optic disc pit. Ophthalmology 2005;112:14301435.

9. Theodossiadis GP. Treatment of maculopathy associated with optic disc pit by sponge explant. Am J Ophthalmol 1996; 121:630-637.

10. Hasegawa T, Akiba J, Ishiko S, et al. Abnormal vitreous structure in optic nerve pit. Jpn J Ophthalmol 1997;41:324327.

11. Oltulu R, Şahin A, Kerimoğlu H. Bilateral optic pit maculopathy: case report. Turkiye Klinikleri J Med Sci 2011;31:1271-1273.

12. Lee KJ, Peyman GA. Surgical management of retinal detachment associated with optic nerve pit. Int Ophthalmol 1993; 17:105-107.

13. Snead MP, James N, Jacobs PM. Vitrectomy, argon laser, and gas tamponade for serous retinal detachment associated with an optic disc pit: a case report. Br J Ophthalmol 1991;75: 381-382.

14. Hirakata A, Hida T, Wakabayashi T, Fukuda M. Unusual posterior hyaloid strand in a young child with optic disc pit maculopathy: intraoperative and histopathological findings. Jpn J Ophthalmol 2005; 49:264-266.

15. Ishikawa K, Terasaki H, Mori M, Sugita K, Miyake Y. Optical coherence tomography before and after vitrectomy with internal limiting membrane removal in a child with optic disc pit maculopathy. Jpn J Ophthalmol 2005;49:411-413.

16. Ghosh YK, Banerjee S, Konstantinidis A, Athanasiadis I, Kirkby GR, Tyagi AK. Surgical management of optic disc pit associated maculopathy. Eur J Ophthalmol 2008;18:142146.

17. Georgalas I, Kouri A, Ladas I, Gotzaridis E. Optic disc pit maculopathy treated with vitrectomy, internal limiting membrane peeling, and air in a 5-year-old boy. Can J Ophthalmol 2010;45:189-191. 